\title{
Problematika Pelafalan Huruf Hijaiyah pada Anak Usia Dini di Rhoudhotu Tarbiyatil Qur'an (RTQ) Al-Ghozali Tlogomas Malang
}

\section{The Difficulties of Pronouncing Hijaiyah Letters among Young Learners of Rhoudhotu Tarbiyatil Qur'an (RTQ) Al-Ghozali Tlogomas Malang}

\author{
Diandra Ariesta Lily Effendi Al Azhim, Lilik Nur Kholidah* \\ Universitas Negeri Malang, Jl. Semarang No. 5 Malang, Jawa Timur, Indonesia \\ *Penulis korespondensi, Surel: lilik.nur.fs@um.ac.id
}

Paper received: 02-01-2021; revised: 15-01-2021; accepted: 30-01-2021

\begin{abstract}
Abstrak
Penelitian ini dilatarbelakangi oleh kesulitan yang sering dialami anak usia dini dalam proses pembelajaran terkait pelafalan huruf hijaiyah, dimana anak kurang dapat melafalkan huruf-huruf hijaiyah dengan benar dan tepat. Penelitian ini memiliki rumusan masalah terkait problematika pelafalan huruf hijaiyah dan faktor yang menyebabkan problematika pelafalan huruf hijaiyah pada anak usia dini di di Rhoudhotu Tarbiyatil Qur'an (RTQ) Al-Ghozali Tlogomas Malang. Tujuan penelitian ini adalah untuk mendeskripsikan bentuk-bentuk problematika pelafalan huruf hijaiyah dan faktor yang mempengaruhi pelafalan huruf hijaiyah pada anak usia dini. Penelitian ini merupakan penelitian kualitatif bersifat deskriptif. Adapun data yang digunakan adalah data kualitatif pelafalan huruf hijaiyah pada anak usia dini. Sumber data penelitian ini adalah anak usia dini di RTQ Al-Ghozali Tlogomas Malang. Adapun teknik pengumpulan datanya menggunakan metode observasi, wawancara, studi pustaka dan dokumentasi. Landasan teori yang digunakan adalah pembelajaran baca tulis Al-Qur'an pada anak usia dini, problematika pelafalan huruf hijaiyah dan faktor yang mempengaruhi pelafalan huruf hijaiyah pada anak usia dini. Berdasarkan hasil penelitian yang dilakukan diperoleh kesimpulan bahwa problematika pelafalan huruf hijaiyah pada anak usia dini yang terjadi adalah perubahan fonem dari tebal menjadi tipis; perubahan fonem karena artikulasi berdekatan; dan kurang dapat membedakan huruf yang karakteristiknya mirip. Adapun faktor penyebab problematika pelafalan huruf hijaiyah pada anak usia dini adalah faktor lingkungan keluarga, kurangnya minat belajar pada anak usia dini, dan faktor individu anak. Adapun solusi dari problematika pelafalan huruf hijaiyah pada anak usia dini adalah perlu adanya perhatian ق khusus pada anak dalam berlatih melafalkan huruf hijaiyah, yaitu huruf
\end{abstract}

Kata kunci: problematika pelafalan, huruf hijaiyah, anak usia dini

\begin{abstract}
This research is motivated by the difficulties that are often experienced by early childhood in the learning process related to the pronunciation of hijaiyah letters, where childrens are less able to pronounce hijaiyah letters correctly. This research has a problem formulation related to the problems of hijaiyah pronunciation and the factors that cause problems with the pronunciation of hijaiyah letters in early childhood in Rhoudhotu Tarbiyatil Qur'an (RTQ) Al-Ghozali Tlogomas Malang. The purpose of this study was to describe the forms of hijaiyah pronunciation problems and the factors that influence the pronunciation of hijaiyah letters in early childhood. This research is a descriptive qualitative research. The data used are qualitative data on the pronunciation of hijaiyah letters in early childhood. The data source of this research is early childhood in RTQ Al-Ghozali Tlogomas Malang. The data collection techniques use the method of observation, interviews, literature study and documentation. The theoretical basis used is learning to read and write AlQur'an in early childhood, problems with the pronunciation of hijaiyah letters and the factors that affect the pronunciation of hijaiyah letters in early childhood. Based on the results of the research
\end{abstract}


conducted, it was concluded that the problematic pronunciation of hijaiyah letters in early childhood that occurs is the change in phonemes from thick to thin; phoneme changes due to adjacent articulations; and less able to distinguish letters with similar characteristics. The factors that cause problems with the pronunciation of hijaiyah letters in early childhood are environmental and family factors, lack of interest in learning in early childhood, and individual child factors. The solution to the problem of pronouncing hijaiyah letters in early childhood needs special attention to children in practicing hijaiyah letters, especially the letters ق ق ع. خ, ح, ش, ز, ذ, ض,

Keywords: pronunciation problems, hijaiyah letters, early childhood

\section{Pendahuluan}

Al-Qur'an merupakan petunjuk dan pedoman utama bagi umat muslim di dunia. AlQuran juga merupakan sumber dari segala ilmu pengetahuan, yang dijadikan pegangan dan acuan umat muslim sepanjang zaman. Dalam Islam pedoman hidup yang terbaik adalah AlQuran yang diturunkan oleh Nabi Muhammad SAW melalui malaikat Jibril. Al-Qur'an berperan sebagai: 1) sumber hukum agama islam, 2) pedoman bagi umat manusia dalam menjalankan kehidupan, 3) pembeda antara yang hak dan yang batil, serta 4) cahaya dan penyejuk bagi manusia. Peran Al-Quran tersebut tentunya menjadi pedoman para orang tua dalam mendidik dan membimbing anak-anaknya.

Pembelajaran baca tulis Al-Qur'an pembelajaran mengenai cara membaca, menulis dan melafalkan huruf Al-Qur'an seperti makharijul huruf, panjang pendek, kaidah tajwid dan ghorib sehingga tidak terjadi perubahan makna. Ada beberapa metode pembelajaran al-Qur'an yang sudah diterapkan di Indonesia, diantaranya adalah metode Iqro', Yanbu'a, Qiroati, Ummi, Bilqalam dan Tikrar (Wicaksono \& Inayati, 2018).

Metode Yanbu'a adalah salah satu metode pembelajaran Al-Qur'an yang unik, yang sesuai dengan karakteristik anak usia dini. Sebab metode ini melibatkan 3 aspek, yaitu visual, auditori, dan kinestetik. Dimana ketiga aspek tersebut saling melengkapi, sehingga kemampuan anak dalam belajar akan berkembang secara seimbang. Menurut Arwani (2009), Pengambilan nama Yanbu'a yang berarti sumber, mengambil dari kata Yanbu'ul Qur'an yang artinya sumber Al-Qur'an. Adapun tujuan dari Yanbu'a sebagai berikut: (1) Andil dalam mencerdaskan anak bangsa agar dapat membaca Al-Qur'an dengan benar dan lancar. (2) Nasyrul Ilmi (menyebarkan ilmu) Al-Qur'an. (3) Memasyarakatkan Al-Qur'an dengan Rasm Utsmani. (4) Membetulkan yang salah dan menyempurnakan yang kurang. (5) Mengajak untuk selalu mendarus Al Quran dan Musyafahah Alquran sampai khatam

Sedangkan sasaran yang harus dicapai pada pembelajaran Al-Qur'anmetode Yanbu'a antara lain: (1) Dapat membaca Al-Qur'an dengan tartil (Makhorijul Huruf, Tajwid, dll), (2) Mengerti bacaan shalat dan gerakannya, (3) Hafal surat-surat pendek dan doa, dan (4) Mampu menulis Arab dengan baik dan benar. Sistem pembelajaran Al-Qur'an di berbagai lembaga Taman Pendidikan Al-Qur'an (TPQ) khususnya Metode Yanbu'a, menggunakan teori mengajar Musyafahah karena dinilai sesuai dan bagus untuk mencapai hasil pembelajaran yang maksimal. Menurut Arwani (2009), belajar Al Qur'an yang biasa disebut Musyafahah ada 3 (tiga) macam:

1. Guru membaca dulu kemudian murid menirukan

2. Murid membaca dan guru mendengarkan apabila ada kesalahan maka dibetulkan

3. Guru membaca, murid mendengarkan 
Mengenalkan Al-Qur'an kepada anak usia dini disebut sebagai metode utama membentuk kepribadian anak. Anak usia dini hendaknya dibiasakan pada pola hidup yang islami dengan norma agama, sosial, kognitif dan Bahasa. Menurut Mamlu'ah (2018), penanaman kemampuan membaca Huruf Hijaiyah merupakan suatu hal yang sudah lazim bagi Taman Pendidikan Al-Qur'an.

Dari kebanyakan peserta didik di Taman Pendidikan Al-Qur'an lainnya, banyak anak yang merasa kesulitan dalam mempelajari Al-Qur'an, khususnya dalam hal membaca dan melafalkan (Widodo dkk, 2017). Rasulullah SAW telah memberikan anjuran untuk mempelajari AlQuran sejak usia dini. Hal ini dikarenakan pada masa anak usia terkandung potensi belajar yang sangat kuat dan besar. Anak akan lebih cepat tanggap dalam menangkap hal-hal yang diajarkan, sehingga mudah menerima pelajaran-pelajaran yang diberikan, (Tanfidiyah, 2017). Sehingga, usia dini merupakan usia yang sangat tepat untuk memperkenalkan dan mempelajari tentang Al-Qur'an apalagi menghafalkannya.

Adapun anak usia dini adalah dapat dikategorikan sebagai anak yang berusia tiga sampai tujuh tahun. Pada usia ini adalah tahap awal proses pertumbuhan dan perkembangan. Dalam perkembangan anak usia dini, terdapat tiga aspek yang mendasari perkembangan anak usia dini, yaitu perkembangan fisik, perkembangan kognitif atau disebut juga perkembangan intelektual serta perkembangan sosial dan emosional. Usia dini merupakan masa penting bagi tumbuh kembang anak yang sering disebut sebagai golden age atau usia keemasan. Usia dini juga disebut sebagai masa yang paling penting bagi perkembangan anak. Hal ini dikarenakan jika seorang anak kurang mendapat perhatian dalam hal pendidikan dan lainnya, maka anak tidak dapat tumbuh dan berkembang secara optimal.

Pendidikan anak usia dini adalah hal utama untuk merangsang dan memaksimalkan aspek perkembangannya. Salah satunya adalah perkembangan kognitif. Menurut Kemendikbud (2014), indikator aspek perkembangan kognitif anak usia dini melalui Standar Tingkat Pencapaian Perkembangan Anak (STPPA) yang tercantum pada Permendikbud 137 tahun 2014. STPPA merupakan kriteria kemampuan yang dicapai anak pada seluruh aspek perkembangan dan pertumbuhan, mencakup aspek agama dan moral, fisik motorik, kognitif, bahasa, sosial-emosional, serta seni.

Pembelajaran diartikan sebagai proses yang terjadi dalam setiap aktivitas keseharian dalam dunia pendidikan. Dalam proses pembelajaran, tentunya ditemukan kesalahan atau problematika. Hal ini merupakan suatu kewajaran terlebih bagi seseorang yang baru mempelajari suatu hal. Problematika yang sering dijumpai pada bidang bahasa adalah berkaitan dengan linguistik, seperti semantik, morfologi, dan fonologi, atau yang biasa kita sebut pelafalan. Menurut Amrulloh dan Hasanah (2019), kesalahan fonologi adalah kesalahan bahasa dalam pengucapan yang dihasilkan oleh alat ucap manusia sehingga menimbulkan perbedaan makna. Sehingga perlunya ketelitian dalam melafalkan suatu huruf atau kata sesuai dengan artikulasi yang sesuai

Kajian penelitian ini adalah kajian fonologi yang memfokuskan pada pelafalan huruf hijaiyah pada anak usia dini. Penelitian ini secara umum dirumuskan berdasarkan masalah yang dialami anak usia dini di Rhoudhotu Tarbiyatil Qur'an (RTQ) Al-Ghozali Tlogomas Malang dalam pelafalan huruf hijaiyah, terlebih untuk huruf-huruf yang memiliki pelafalan yang hampir sama, seperti w dan ش خ خ dan 
Roudhotu Tarbiyatil Qur'an (RTQ) Al-Ghozali secara resmi berdiri sejak 27 Oktober 2007. Lembaga ini berlokasi di Jl. Kecubung no 10B Tlogomas Malang. Peneliti mengambil objek penelitian di RTQ Al-Ghozali karena banyak sekali anak usia dini yang mengikuti proses belajar mengajar disana, dan juga melihat fenomena yang terjadi dimana banyak anak usia dini yang kesulitan dalam mempelajari Al-Qur'an, khususnya dalam pelafalan huruf-huruf hijaiyah. Dimana anak usia dini yang belajar di Rhoudhotu Tarbiyatil Qur'an (RTQ) Al-Ghozali Tlogomas Malang berkisar tiga sampai enam tahun. Disamping itu, letak Rhoudhotu Tarbiyatil Qur'an (RTQ) Al-Ghozali Tlogomas Malang yang berada di tengah perkotaan dan perumahan, sehingga notabenenya berasal dari kalangan menengah keatas dan orang tua karir. Sehingga peneliti tertarik untuk meneliti permasalahan ini.

Berdasarkan hasil observasi dan wawancara dengan pengajar dan anak didik di RTQ AlGhozali Tlogomas Malang, yang mengungkapkan bahwa pada saat proses pembelajaran berlangsung khususnya dalam pelafalan huruf hijaiyah, anak usia dini belum bisa melafalkan huruf hijaiyah dengan baik dan benar. Berdasarkan fenomena yang terjadi, banyak kesalahan pelafalan huruf-huruf hijaiyah yang sering dialami oleh anak usia dini. Adapun beberapa kesalahan pelafalan huruf hijaiyah yang sering terjadi pada anak usia dini, diantaranya قesalahan dalam melafalkan huruf ق ع خ, ح, ش, ز, ذ, ض, dan huruf

Berikut ini adalah beberapa penelitian terdahulu yang juga membahas tentang problematika pelafalan huruf hijaiyah. Pertama, penelitian oleh Fachri (2019) yang berjudul "Analisis Kesalahan Fonologi dalam Membaca Teks Bahasa Arab Mata Pelajaran Bahasa Arab Siswa Kelas 5B SD Al-Irsyad Al-Islamiyyah Semarang Tahun Pelajaran 2018/2019”. Hasil skripsi M Iwan Fachri menyatakan bahwa bentuk kesalahan fonologi dalam membaca teks Bahasa Arab yaitu perubahan fonem, pengurangan fonem dan tidak dapat membedakan huruf yang bentuknya hampir sama.

Kedua, penelitian oleh Putri (2017) yang berjudul "Analisis Kesalahan Pelafalan Huruf Hijaiyah dalam Membaca Teks Arab: Studi Deskriptif Kualitatif pada Kelas X-IPS MA Insan Mandiri Tahun Ajaran 2016/2017". Hasil skripsi Nadya Domma Putri menyatakan bahwa terdapat beberapa kesalahan pelafalan yang sering terjadi salah satunya adalah pada makhraj halqi (tenggorokan), dan sifat Hams, Ithbaq, Ishmat, Shafir, Qalqalah, dan Tafasyi.

Ketiga, penelitian oleh Rahayu (2016) yang berjudul Analisis Kesalahan Fonologi dalam Membaca Teks Bahasa Arab Siswa Kelas VIII G MTSN Piyungan Bantul. Hasil skripsi Nenin Arum Sari Rahayu menyatakan bahwa kesalahan membaca teks berbahasa Arab ada tiga yaitu penambahan fonem, penghilangan fonem dan perubahan fonem. Faktor penyebabnya adalah karakteristik bahasa yang berbeda, serta kurangnya motivasi siswa dalam pelajaran Bahasa Arab.

Berdasarkan tiga penelitian terdahulu yang telah dijabarkan diatas, ditemukan kesamaan dalam kajian, yaitu terkait analisis kesalahan pelafalan atau fonologi dalam bahasa Arab. Selain mempunyai kesamaan, ketiga peneliti di atas, terdapat perbedaan yang ada. yakni dari segi sekolah atau lembaga, waktu, kelas atau jenjang, serta metode yang digunakan. Peneliti meneliti problematika pelafalan yang difokuskan pada anak usia dini di RTQ Al-Ghozali Malang.

Sehingga dengan adanya permasalahan ini, penelitian yang akan disusun ini bertujuan mendeskripsikan problematika yang sering kali dialami oleh anak usia dini dalam melafalkan 
huruf hijaiyah. Oleh karena itu, dalam penyusunan penelitian ini, peneliti memilih judul: "Problematika Pelafalan Huruf Hijaiyah pada Anak Usia Dini di Rhoudhotu Tarbiyatil Qur'an (RTQ) Al-Ghozali Tlogomas Malang".

\section{Metode}

Penelitian ini menggunakan penelitian kualitatif yang bersifat deskriptif. Tujuan penelitian adalah untuk mendeskripsikan, membuat gambaran secara sistematis, fokus, dan akurat mengenai fakta-fakta, sifat-sifat, serta hubungan antar fenomena yang diteliti (Ainin, 2007:67). Penelitian ini dilakukan dengan mendapatkan gambaran atau deskripsi yang jelas tentang kegiatan pembelajaran Al-Qur'an yang ada di di Rhoudhotu Tarbiyatil Qur'an (RTQ) AlGhozali Tlogomas Malang, problematika pelafalan huruf hijaiyah pada anak usia dini dan faktor yang mempengaruhi pelafalan huruf hijaiyah pada anak usia dini.

Adapun tujuan dari penelitian ini adalah (1) mendeskripsikan problematikaproblematika pelafalan huruf hijaiyah pada anak usia dini dan (2) mendeskripsikan faktor yang mempengaruhi pelafalan huruf hijaiyah pada anak usia dini. Dalam penelitian ini, peneliti berperan sebagai human instrument dengan berpegang pada dua pedoman, yaitu:

a. Pedoman wawancara yang digunakan penulis sebagai pedoman saat melakukan wawancara kepada narasumber, yaitu kepala Lembaga dan pengajar. Adapun pedoman wawancara yang digunakan adalah:

1. Problematika yang terjadi dalam proses pembelajaran membaca dan melafalkan huruf hijaiyah bagi anak usia dini di RTQ Al-Ghozali Tlogomas

2. Upaya untuk mengatasi problematika pelafalan huruf hijaiyah pada anak usia dini di RTQ Al-Ghozali Tlogomas

3. Metode yang digunakan dalam proses pembelajaran terkait pelafalan huruf hijaiyah bagi anak usia dini di RTQ Al-Ghozali Tlogomas

4. Sarana dan prasarana dalam proses pembelajaran terkait pelafalan huruf hijaiyah bagi anak usia dini di RTQ Al-Ghozali Tlogomas

5. Faktor penyebab anak usia dini kurang mampu dalam membaca dan melafalkan huruf hijaiyah dengan baik dan benar

6. Evaluasi yang dilakukan guru pengajar dalam pelafalan huruf hijaiyah pada anak usia dini di RTQ Al-Ghozali Tlogomas

b. Pedoman observasi, yang digunakan sebagai pedoman saat melakukan pengamatan ketika pembelajaran di RTQ Al-Ghozali Tlogomas Malang dilaksanakan, dan data dari hasil observasi digunakan untuk memperkuat data yang didapat saat wawancara. Adapun pedoman observasi pada penelitian ini adalah:

1. Gambaran kondisi fisik lokasi penelitian di RTQ Al-Ghozali Tlogomas Malang

2. Suasana dan kegiatan pembelajaran di RTQ Al-Ghozali Tlogomas Malang

3. Sarana dan Prasarana pembelajaran di RTQ Al-Ghozali Tlogomas Malang

Data dalam penelitian ini adalah berupa data kualitatif pelafalan huruf hijaiyah anak usia dini. Sedangkan sumber data penelitian ini adalah anak usia dini di Lembaga RTQ Al-Ghozali Jl. Kecubung No.10B, Kel.Tlogomas, Kec, Lowokwaru, Kota Malang. Pengumpulan data dilakukan oleh penulis untuk memperoleh data-data yang dibutuhkannya. Adapun teknik untuk mengumpulkan data tersebut diantaranya: a) Observasi yang dilakukan di RTQ Al-Ghozali Jl. Kecubung No.10B, Kel.Tlogomas, Kec, Lowokwaru, Kota Malang, pada bulan Oktober sampai 
November 2020 dengan mengamati proses pembelajaran, dan problematika apa saja yang terjadi ketika melafalkan huruf hijaiyah dan faktor penyebabnya. b) Wawancara kepada kepala lembaga dan guru pengajar di RTQ Al-Ghozali Tlogomas Malang, c) Studi kasus dengan cara mengumpulkan catatan, hasil wawancara, dokumen untuk menunjang penelitian ini dengan mencari referensi, d) Dokumentasi berupa gambar, foto, dan teks tertulis mengenai keadaan lembaga, seperti latar belakang dan struktur kelembagaan di RTQ Al-Ghozali Tlogomas Malang, data santri serta foto objek penelitian, dan pada saat kegiatan pembelajaran berlangsung.

Setelah pengumpulan data, maka langkah selanjutnya adalah analisis data. Analisis data dalam penelitian ini menggunakan analisis berdasarkan penalaran logika. Setelah data didapatkan dan terkumpul kemudian penulis melakukan analisis data yang sudah terkumpul. Analisis data dapat dilakukan secara bertahap dengan cara: (1) pengumpulan data (2) memilah dan menyeleksi data-data yang diperoleh; (3) penyajian data: mendeskripsikan hasil penelitian secara sistematis dan rinci; dan (4) penarikan kesimpulan dari hasil analisis

\section{Hasil dan Pembahasan}

\subsection{Hasil}

Melalui hasil wawancara dan observasi yang telah peneliti lakukan di RTQ Al-Ghozali Tlogomas Malang, dapat diketahui bahwa problematika pelafalan huruf hijaiyah pada anak usia dini bisa dijabarkan melalui pemaparan klasifikasi kesalahan berikut:

Tabel 1. Problematika pelafalan pada huruf hijaiyah

\begin{tabular}{cc}
\hline Huruf Hijaiyah & Problematika Pelafalan \\
\hline$\varepsilon$ & $\varsigma$ \\
\hline$\dot{\tau}$ & $\tau$ \\
\hline$\tau$ & 0 \\
\hline$\dot{\omega}$ & $\omega$ \\
\hline$j$ & $ج$ \\
\hline$\dot{1}$ & $j$ \\
\hline$\dot{H}$ & $\dot{\omega}$ \\
\hline$\dot{H}$ & $\omega$ \\
\hline$\dot{H}$ & 5 \\
\hline$\dot{\varepsilon}$ & $د$ \\
\hline
\end{tabular}

Berdasarkan tabel yang dijabarkan diatas, maka problematika pelafalan huruf hijaiyah pada anak usia dini RTQ Al-Ghozali Tlogomas Malang jika dipresentasikan dari seluruh jumlah kesalahan sebesar 60\% atau 18 dari 29 kesalahan huruf hijaiyah. Adapun penjelasan dari problematika diatas, akan diuraikan sebagai berikut: 
a. Problematika pelafalan huruf $\varepsilon$ menjadi \&

Problematika pelafalan kedua huruf ini sering terjadi pada anak usia dini. Banyak dari mereka yang salah melafalkan huruf $\varepsilon$ menjadi $ء$. Pada bahasa Indonesia, huruf $\varepsilon$ dalam pelafalannya jarang ditemukan pada pelafalan bahasa Indonesia. Hal ini menjadikan anak lebih dapat melafalkan huruf $s$, karena lebih mudah dan lebih sering diucapkan. Letak artikulasi yang berdekatan juga menyebabkan problematika dalam pelafalan kedua huruf ini. Letak artikulasi huruf $\varepsilon$ berada di tengah tenggorokan, sedangkan letak artikulasi huruf $\varepsilon$ berada di pangkal tenggorokan atau tenggorokan bagian tengah. Hal tersebut menjadikan anak sering salah dalam pelafalan huruf $\varepsilon$ menjadi huruf $\&$

b. Problematika pelafalan huruf $\dot{\tau}$ menjadi $\tau$

Problematika pelafalan huruf $\dot{\tau}$ menjadi $\tau$ banyak terjadi pada anak usia dini karena terdapat kemiripan antara huruf $\dot{\tau}$ dan $\tau$. Pelafalan huruf $\dot{z}$ lebih berat daripada huruf $\tau$, dan juga dalam bahasa Indonesia pelafalan 'ha' lebih sering digunakan daripada pelafalan 'kha'. Pelafalan huruf $\tau$ lebih mudah diterapkan oleh anak usia dini yang baru mempelajari hurufhuruf, daripada pelafalan huruf $\dot{\tau}$. Sehingga anak lebih sering melafalkan huruf $\dot{\tau}$ menjadi $\tau$. Begitu pula letak artikulasi huruf $\dot{z}$ berada di puncak tenggorokan, atau tenggorokan bagian atas, sedangkan huruf $₹$ berada di tengah tenggorokan atau tenggorokan bagian tengah. Kedua huruf ini sering salah dilafalkan oleh anak usia dini di RTQ Al-Ghozali Tlogomas Malang

\section{c. Problematika pelafalan huruf $z$ menjadi $\diamond$}

Problematika pelafalan huruf $₹$ menjadi $\bowtie$ seringkali dialami oleh anak usia dini. Bahasa Indonesia merupakan salah satu penyebab kesalahan kedua huruf ini. Huruf $ح$ memiliki pelafalan yang tipis, berbeda dengan huruf $₫$ yang memiliki pelafalan lebih berat. Letak artikulasi huruf $\tau$ berada di tengah tenggorokan, sedangkan huruf $₫$ berada di pangkal tenggorokan atau tenggorokan bagian bawah. Maka dari itu banyak sekali kesalahan yang terjadi diantara kedua huruf tersebut, sehingga diperlukan pembiasaan agar anak dapat membedakan dan melafalkan huruf tersebut dengan benar.

d. Problematika pelafalan huruf ش menjadi w

Problematika pelafalan huruf ش menjadi wanyak terjadi dikalangan anak usia dini. Anak cenderung melafalkan huruf ش ف ش dengan pelafalan yang sama dengan huruf werlebih bagi anak usia dini yang pelafalannya masih belum baik, mereka cenderung lebih mudah dengan melafalkannya menggunakan huruf 's'. Letak artikulasi pada huruf ش berada di tengah lidah dan tengah langit-langit, sedangkan huruf w berada di ujung lidah yang menghadap dan mendekat diantara kedua gigi seri (atas dan bawah).

e. Problematika pelafalan huruf jmenjadi ج

Problematika pelafalan huruf j menjadi $\underset{j}{ }$, terjadi karena pelafalan anak yang masih belum baik dan benar, sehingga terkadang anak melafalkannya salah. Adapun letak artikulasi huruf $j$ berada di ujung lidah yang menghadap dan mendekat diantara kedua gigi seri (atas dan bawah), sedangkan huruf ج berada di bagian tengah lidah dan tengah langit-langit. Hal ini menjadikan penyebab anak usia dini masih sering salah dalam melafalkan huruf tersebut.

f. Problematika pelafalan huruf $\dot{j}$ menjadi j

Problematika pelafalan huruf ذ menjadi jsangat sering terjadi pada anak usia dini, karena pelafalan kedua huruf tersebut hamper sama yaitu antara 'dza' dan 'za', tetapi dalam 
bahasa Indonesia pelafalan 'za' lebih banyak digunakan. Letak artikulasi juga berpengaruh, yaitu huruf ذ yang berada di ujung lidah dan ujung dua buah gigi seri bagian atas, sedangkan huruf $j$ berada di ujung lidah yang menghadap dan mendekat diantara dua gigi seri (atas dan bawah).

\section{g. Problematika pelafalan huruf ض menjadi}

Pengucapan antara dua huruf ini, yaitu ض ظ ban dang terjadi kesalahan, baik itu terbalik satu sama lain ataupun pengucapan awal yang salah. Dalam Bahasa Indonesia kita mengenal huruf 'd' sedangkan dalam bahasa arab kita mengenal huruf ض yang dilafalkan sebagai 'dho' dan huruf ظ yang dilafalkan sebagai 'dhlo', yang mana hal ini tidak terdapat pada pelafalan bahasa Indonesia yang biasa kita gunakan. Maka dari itu banyak yang mengalami kesulitan dalam melafalkan kedua huruf, terlebih pada anak usia dini yang masih baru mempelajari huruf hijaiyah. Letak artikulasi huruf ض berada di bagian kanan dan kiri lidah yang mengenai bagian gusi geraham atas sebelah dalam, sedangkan huruf ظ letak artikulasinya berada di ujung lidah serta ujung dari dua gigi seri pertama yang atas.

\section{h. Problematika pelafalan huruf $ث$ menjadi w}

Problematika pelafalan huruf ث menjadi huruf w juga kelak terjadi di kalangan anak usia dini. Kita ketahui bahwa secara bahasa Indonesia huruf w lebih banyak dipakai dan dilafalkan pada bahasa sehari-hari, berbeda dengan huruf $\doteq$ yang hanya dimiliki pada huruf arab. Adapun letak artikulasi yang berdekatan juga mempengaruhi kesalahan pelafalan kedua huruf ini. Letak artikulasi huruf w berada di ujung lidah yang menghadap dan mendekat diantara kedua gigi seri (atas dan bawah), sedangkan letak artikulasi huruf $ث$ berada di ujung lidah dan ujung dari dua gigi seri pertama yang atas.

\section{i. Problematika pelafalan huruf قmenjadi}

Problematika ini seringkali ditemukan karena huruf قang dilambangkan dengan huruf ' $q$ ' yang mana jarang sekali ditemukan pada bahasa Indonesia. Huruf ق termasuk huruf yang pelafalannya tebal dan berat, berbeda dengan huruf 5 yang pelafalannya tipis dan ringan, serta digunakan dalam bahasa Indonesia. Letak artikulasi yang berdekatan juga mempengaruhi kesalahan dalam pelafalan kedua huruf ini. Huruf قletak artikulasinya berada di pangkal dari lidah yang mengenai langit-langit di atasnya. Adapun letak artikulasi huruf 5 berada di pangkal dari lidah yang agak kedepan mengenai langit-langit. Sehingga hal ini menyebabkan anak lebih ق cenderung melafalkan . ك

\section{j. Problematika pelafalan huruf $\doteq$ menjadi $ت$}

Problematika pelafalan huruf $\doteq$ menjadi $ت$ sering terjadi karena huruf $\doteq$ yang jarang ditemukan pada penggunaan bahasa Indonesia, berbeda dengan huruf $ت$. Dan anak cenderung kesulitan dalam melafalkan huruf 'tsa', karena pelafalan anak usia dini yang juga masih belum baik. Letak artikulasi yang berdekatan juga menjadi penyebab kesalahan pelafalan kedua huruf ini, yaitu huruf $ث$ yang berada pada ujung lidah dan ujung dari dua gigi seri pertama yang atas, sedangkan letak artikulasi huruf $ت$ berada di punggung dari ujung lidah yang mengenai pangkal gigi seri pertama yang atas sampai mengenai gusinya. Maka dari itu, dalam melafalkan kedua huruf ini sering terjadi kesalahan, terlebih pada anak usia dini. 
k. Problematika pelafalan huruf $\lrcorner$ menjadi د

Problematika pelafalan huruf $\dot{j}$ menjadi $د$ juga banyak ditemukan pada anak usia dini karena terdapat kemiripan tulisan maupun pelafalan antara huruf $\dot{j}$ dengan huruf $د$. Letak artikulasi yang berdekatan menyebabkan anak sering salah melafalkan kedua huruf ini. Letak artikulasi huruf ذ ذ berada di ujung lidah dan ujung dari dua gigi seri pertama yang atas, sedangkan huruf $د$ yang berada di punggung dari ujung lidah yang mengenai pangkal gigi seri pertama yang atas sampai mengenai gusinya. Maka dari itu, dalam melafalkan kedua huruf ini sering terjadi kesalahan, terlebih bagi anak usia dini.

l. Problematika pelafalan huruf $\dot{\varepsilon}$ menjadi $\varepsilon$

Problematika pelafalan huruf $\dot{\varepsilon}$ menjadi $\varepsilon$ terjadi karena anak usia dini tidak terlalu teliti dalam memperhatikan huruf yang memiliki titik dan huruf yang tidak memiliki titik, sehingga terkadang sering terjadi kesalahan karena huruf yang tertukar. Terlebih lagi bentuk huruf yang sama dan letak artikulasinya yang berdekatan. Letak artikulasi pada huruf $\dot{\varepsilon}$ yang terletak di tenggorokan bagian atas, sedangkan letak artikulasi huruf $\varepsilon$ di tenggorokan bagian tengah. Hal ini menjadi penyebab anak sering salah dalam membedakan dan melafalkan huruf tersebut.

Berdasarkan hasil wawancara dan observasi, peneliti mengklasifikasikan beberapa faktor yang mempengaruhi problematika pelafalan huruf hijaiyah pada anak usia dini adalah sebagai berikut

\section{a. Faktor Lingkungan Keluarga}

Berdasarkan hasil pengumpulan data terkait problematika pelafalan huruf hijaiyah pada anak usia dini ini kebanyakan dari orang tua kurang maksimal dalam memberikan perhatian pada anak. Sehingga ketika proses pembelajaran kurang efektif, karena hanya dipelajari ketika di RTQ Al-Ghozali Tlogomas Malang. Berbeda jika dalam keluarga sudah dibiasakan untuk belajar agama dan Al-Qur'an, maka dalam pembelajaran di RTQ akan lebih mudah karena sudah dipelajari dan dibiasakan di rumah.

Banyak juga anak usia dini yang memiliki gangguan pelafalan, yaitu keterlambatan berbicara. Terlebih mayoritas anak usia dini di RTQ Al-Ghozali Tlogomas Malang, umurnya berkisar tiga sampai enam tahun. Hal ini juga merupakan dampak dari pola asuh orang tua yang kurang optimal dimana pada fase perkembangan anak usia dini yang sangat penting tidak diperhatikan oleh para orang tua. Anak yang mengalami keterlambatan berbicara adalah anak yang kemampuan berbicaranya tidak sama dengan anak lain seusianya.

Mayoritas anak yang belajar di RTQ Al-Ghozali Tlogomas Malang memiliki orang tua yang bekerja di kantor dan rata-rata berada di kalangan menengah ke atas, sehingga waktu yang dimiliki orang tua untuk perhatikan perkembangan anaknya berkurang. Hal itu merupakan salah satu penyebab anak usia dini yang mengalami keterlambatan bahasa (Speech Delay), dimana anak belum bisa melafalkan huruf atau kata dengan baik, berbeda dengan anak lain seusianya yang mungkin perkembangan kognitif khususnya bahasa lebih baik.

\section{b. Kurangnya Minat Belajar Anak}

Berdasarkan hasil observasi, di RTQ Al-Ghozali, banyak anak usia dini yang masih memiliki minat belajar yang kurang, sehingga berpengaruh secara langsung terhadap proses pembelajaran. Terlebih subjek penelitian adalah anak usia dini yang sangat susah belajar dan berkonsentrasi. Anak cenderung senang untuk bermain, sibuk sendiri, tidak fokus dalam 
pembelajaran, tidak mengikuti arahan guru dan sebagainya. Terlebih untuk anak usia dini yang mana mereka lebih tertarik untuk bermain daripada belajar

Saat proses pembelajaran di RTQ Al-Ghozali Tlogomas Malang, banyak anak yang tidak fokus dan tidak memperhatikan ketika guru melakukan pembacaan klasikal. Anak cenderung lebih tertarik dengan kesibukannya masing-masing. Sehingga perlu dilakukan upaya untuk memusatkan perhatian anak dalam proses pembelajaran. Begitu juga ketika baca simak didepan kelas, anak seringkali tidak fokus dan bermain sendiri.

\section{c. Faktor Individu Anak}

Berdasarkan hasil observasi, peneliti melihat bahwa perkembangan anak pada tiap individu tentunya berbeda-beda, sehingga kemampuan tiap anak dalam melafalkan hurufhuruf hijaiyah juga berbeda. Beberapa anak memiliki pelafalan yang sudah benar, dan beberapa anak lainnya memiliki kekurangan dalam segi pelafalan. Hal ini dikarenakan rentang anak usia dini di RTQ Al-Ghozali dimulai dari umur tiga sampai enam tahun. Sehingga memiliki tingkat perkembangan kognitif dan tingkat konsentrasi yang berbeda-beda.

\subsection{Pembahasan}

Berdasarkan penjabaran klasifikasi kesalahan pelafalan yang dialami anak usia dini di RTQ Al-Ghozali Tlogomas Malang, maka dapat diuraikan sebagai berikut:

a. Perubahan fonem dari tebal menjadi tipis

Perubahan ini terjadi pada huruf $\dot{\tau}$ yang dibaca seperti huruf $\tau$. Hal ini terjadi karena huruf $\dot{\tau}$ memiliki pelafalan yang berat, dan bagi anak usia dini lebih mudah untuk melafalkan huruf $\tau$.

Contoh lainnya ada pada huruf شyang dibaca seperti huruf س س ش memiliki pelafalan yang berat, sedangkan huruf wemiliki pelafalan yang tipis. Adapun huruf قuga sering salah dalam pelafalannya, huruf ق dilafalkan seperti huruf كuruf. Huruf termasuk huruf yang pelafalannya tebal, sedangkan huruf s pelafalannya lebih ringan. Hal ini menjadikan kedua huruf tersebut sering terjadi kesalahan dalam pengucapan.

b. Perubahan fonem karena artikulasi berdekatan

Perubahan fonem karena artikulasi berdekatan terjadi pada huruf j yang dibaca menjadi د. Hal ini sering terjadi karena letak artikulasi yang berdekatan, sehingga sering menimbulkan kesalahan pada pelafalannya. letak artikulasi huruf $ذ$ berada di ujung lidah dan ujung dari dua gigi seri pertama atas, sedangkan huruf s yang berada di ujung lidah menyentuh pangkal dari gigi seri pertama bagian atas sampai mengenai gusi.

Contoh lain adalah huruf $ث$ yang dibaca menjadi $ت$. Hal ini sering terjadi, karena letak artikulasinya berdekatan ' $₫$ ' yang berada pada ujung lidah dan ujung dari dua gigi seri pertama yang atas, sedangkan huruf ' $"$ ' berada pada punggung dari ujung lidah yang mengenai pangkal gigi seri pertama yang atas mengenai gusi.

Menurut Arwani (2009) makhorijul huruf dibagi menjadi 17, yaitu:

1. Rongga mulut dan tenggorokan yaitu huruf mad.

2. Pangkal tenggorokan yaitu huruf $₫$ dan 。

3. Pertengahan tenggorokan yaitu huruf $\varepsilon$ dan $\tau$ 
4. Ujung tenggorokan yaitu huruf $\dot{\varepsilon}$ dan $\dot{\tau}$

5. Pangkal lidah yang mengenai langit-langit di atasnya yaitu huruf

6. Pangkal lidah yang agak kedepan mengenai langit-langit yaitu huruf

7. ش.ش. ي Tengah-tengah lidah menepati langit-langit yaitu huruf

8. Tepi lidah bagian kanan dan kiri mengenai sisi gusi geraham atas dalam yaitu huruf

9. Tepi lidah kanan atau kiri bagian depan menepati gusi pada gigi seri pertama yang atas yaitu huruf $J$

10. Ujung lidah yang mengenai gusi gigi seri pertama yang atas yaitu huruf ن

11. Ujung lidah agak kedalam menepati gusi gigi seri yang pertama yaitu huruf,

12. Punggung dari ujung lidah yang mengenai pangkal gigi seri pertama bagian atas sampai mengenai gusinya yaitu huruf

13. Ujung lidah yang menepati antara kedua gigi seri (atas dan bawah) yaitu huruf

14. Ujung lidah menepati ujung dua gigi seri pertama bagian atas yaitu huruf ظ, ذار

15. Bibir bawah bagian dalam yang mengenai ujung gigi seri yang atas yaitu huruf

16. Dua bibir atas dan bawah yaitu huruf

17. Janur atau pangkal hidung yaitu huruf ghunnah

c. Kurang dapat membedakan huruf yang karakteristiknya mirip

Huruf yang sering terbalik dalam pelafalan salah satunya karena bentuk tulisan yang mirip, yang mana titik menjadi penyebab terjadinya kesalahan pada pelafalan anak usia dini, seperti huruf $\varepsilon$ dan $\dot{\tau}, \dot{\varepsilon}$ dan $\tau$.

Perubahan-perubahan ini terjadi karena pengaruh bahasa Ibu (bahasa Indonesia), sehingga kesulitan dalam melafalkan bunyi-bunyi pada huruf-huruf hijaiyah. Menurut Hamid (2013), penutur kesulitan dalam menuturkan bunyi bahasa Arab, dimana bunyi tersebut tidak ada pada bahasa Indonesia, dan juga salah dalam menginterpretasikan bunyi arab yang dianggap sama dengan bunyi dalam bahasa Indonesia

Berdasarkan penjabaran klasifikasi kesalahan pelafalan yang dialami anak usia dini di RTQ Al-Ghozali Tlogomas Malang, maka dapat diuraikan sebagai berikut:

\section{d. Faktor lingkungan keluarga}

Keluarga adalah tempat terpenting dalam tumbuh kembang anak. Peran orang tua sangat penting dalam pembentukan pribadi dan perkembangan anak. Keluarga yang memiliki latar belakang agama, mereka akan mengajarkan agama sejak usia dini, tetapi bagi keluarga yang tidak memiliki latar belakang agama, cenderung mengabaikan pendidikan agama anakanaknya. Keluarga yang baik, tentunya bisa memberikan dorongan dan contoh bagi anak. Terlebih dalam usia dini termasuk masa keemasan (golden age) (Slameto, 2013).

Adapun menurut Hidayat (2017), anak membutuhkan pemeliharaan, pengawasan, dan bimbingan agar pertumbuhan dan perkembangan anak berjalan dengan baik. Lingkungan dapat mempengaruhi tingkah laku individu anak berdasarkan pola asuhan, suasana rumah dan suasana anggota keluarga. Hal ini juga dikemukakan oleh Slameto (2013) bahwa orang tua yang kurang memperhatikan pertumbuhan dan perkembangan anaknya, dan tidak mengatur waktu belajar anaknya dapat menyebabkan keberhasilan anak dalam belajar tidak maksimal. 
Penelitian terbaru menemukan bahwa anak yang sering dibacakan cerita, keterlibatan peran orang tua, dan penyediaan materi pembelajaran sesuai dengan usia anak merupakan hal terpenting bagi perkembangan bahasa anak (Santrock, 2011).

Hal ini menjadi salah satu penyebab anak usia dini yang mengalami keterlambatan bahasa (Speech Delay), dimana anak belum bisa melafalkan huruf atau kata dengan baik, berbeda dengan anak lain seusianya yang mungkin perkembangan kognitif khususnya bahasa lebih baik. Menurut Masitoh (2019), penyebab keterlambatan bahasa pada anak usia dini adalah kurangnya motivasi anak dalam berkomunikasi, dan terbatasnya kesempatan praktik bicara karena ketatnya batasan tentang peluang mereka diperbolehkan berbicara di rumah.

\section{e. Kurangnya minat belajar anak}

Faktor kurangnya minat belajar anak juga menjadi faktor yang sangat berpengaruh terhadap proses dan keberhasilan anak dalam pembelajaran. Menurut Slameto (2013), minat belajar individu anak yang besar akan menghasilkan prestasi yang lebih baik, begitu juga jika minat belajar individu kurang, maka prestasinya akan lebih rendah. Minat adalah hasrat yang muncul dalam diri seseorang pada objek tertentu. Sedangkan motivasi adalah dorongan, yang begitu besar dalam individu untuk mencapai suatu keinginan, atau tujuan tertentu. Minat dan motivasi merupakan dua hal yang sangat berpengaruh bagi keberhasilan anak. Minat belajar individu yang tinggi akan menghasilkan prestasi yang signifikan dibandingkan dengan minat belajar individu yang rendah.

Minat belajar peserta didik dalam mengikuti pembelajaran merupakan hal penting Anak yang minat belajarnya rendah bisa dikenali dari tingkah laku berikut: Tidak fokus dan tidak sungguh-sungguh dalam belajar, cepat bosan dalam belajar, bermalas-malasan dalam belajar, berusaha menghindari kegiatan belajar, sering mengobrol dengan temannya, dan sibuk bermain sendiri.

\section{f. Faktor individu anak}

Adapun mengenai faktor individu anak berkaitan dengan karakter masing-masing anak. Masing-masing individu anak tentunya memiliki karakter dan bakat yang berbeda-beda. Perbedaaan disebabkan oleh pembawaan sejak lahir, apabila berada dilingkungan yang sama, individu-individu itu akan bereaksi berbeda sesuai pembawaan lahir mereka (Tadjuddin, 2017). Menurut Puspita (2013) budaya juga mempengaruhi perkembangan penyesuaian sosial anak. Penyesuaian sosial yang benar, dapat membantu keberhasilan anak. Oleh karena itu, orang dewasa baik orang tua, maupun perlu mengembangkan kesadaran tersebut, seperti:

1. Mengenali bahwa anak itu unik. Mereka mempunyai bakat individu yang khusus, kemampuan dan gaya belajar yang unik. Dalam hal ini, maka kita sebaiknya selalu menghargai perbedaan dan keunikan tersebut, sehingga setiap individu mempunyai kesempatan yang sama dalam perkembangan fisik dan kognitifnya

2. Mengenali, dan menghargai latar belakang anak, terutama orang tua dan pendidik. Dengan cara ini, akan dapat mengenal individu anak dengan baik, sehingga perlakuan terhadap individu sesuai dan adil

3. Menggunakan kegiatan penilaian otentik untuk menila perkembangan pembelajaran dan pertumbuhan anak dengan memperhatikan latar belakang anak 
Menurut Hamid (2013), kesulitan menuturkan bunyi-bunyi huruf Arab adalah pengaruh Bahasa Ibu (bahasa Indonesia), yang berpengaruh pada dua aspek,yaitu:

1. Kebiasaan bahasa Indonesia dapat mendukung proses pembelajaran bahasa Arab, manakala antara kedua bahasa mempunyai pelafalan yang sama

2. Kebiasaan bahasa pertama (bahasa Indonesia) berdampak pada bunyi Arab, keadaan ini berpengaruh pada beberapa aspek:

a) Penutur yang kesulitan melafalkan bunyi bahasa Arab yang tidak ditemukan pada bahasa pertama mereka yaitu Bahasa Indonesia.

b) Penutur mendengarkan bunyi bahasa Arab yang asing bagi mereka kemudian dilafalkan menggunakan bunyi yang ada pada bahasa Indonesia

Menurut Santrock (2011) terdapat tiga studi longitudinal tentang pentingnya keterampilan berbahasa anak dan persiapan anak dalam proses pembelajaran yaitu:

a) Tataran fonologi, dan pengetahuan terkait bunyi serta kecepatan dalam memahami literasi pada anak usia dini sangat berkaitan dengan keberhasilan kognitif anak

b) Lingkungan rumah atau keluarga mempengaruhi keterampilan bahasa pada anak usia dini, sehingga dapat menjadi bekal bagi anak untuk memasuki jenjang berikutnya

c) Pengetahuan anak mengenai huruf-huruf dan pembiasaan yang diterapkan sebelumnya sangat berkorelasi dengan prestasi membaca anak di jenjang berikutnya.

\section{Simpulan}

Berdasarkan hasil penelitian terkait "Problematika Pelafalan Huruf Hijaiyah di Rhoudhotu Tarbiyatil Qur'an (RTQ) Al-Ghozali Tlogomas Malang”, dapat ditarik kesimpulan sebagai berikut: Pertama, problematika pelafalan huruf hijaiyah pada anak usia dini di Rhoudhotu Tarbiyatil Qur'an (RTQ) Al-Ghozali Tlogomas Malang sebagai berikut: a) Perubahan fonem dari tebal menjadi tipis; b) Perubahan fonem karena artikulasi berdekatan; dan c) Kurang dapat membedakan huruf yang karakteristiknya mirip, salah satunya karena bentuk tulisan yang mirip, yang mana titik menjadi penyebab terjadinya kesalahan pada pelafalan anak usia dini

Kedua, faktor yang mempengaruhi pelafalan huruf hijaiyah pada anak usia dini di Rhoudhotu Tarbiyatil Qur'an (RTQ) Al-Ghozali Tlogomas Malang adalah: a) Faktor lingkungan keluarga, dimana peran dari orang tua dan lingkungan sangatlah penting dalam proses belajar dan perkembangan anak, keluarga yang baik, tentunya bisa memberikan dorongan dan contoh bagi anak terlebih dalam usia dini termasuk masa keemasan (golden age). b) Kurangnya minat belajar anak, dimana minat belajar sangat berpengaruh pada keberhasilan proses pembelajaran, minat belajar individu anak yang besar akan menghasilkan prestasi yang lebih baik, begitu juga jika minat belajar individu kurang, maka prestasinya akan lebih rendah. dan c) Faktor individu anak, yang mana perkembangan tiap individu berbeda-beda, sehingga kemampuan melafalkan huruf-huruf hijaiyah juga berbeda. Setiap individu memiliki karakteristik dan kemampuan berbeda-beda.

\section{Daftar Rujukan}

Ainin, M. (2007). Metodologi penelitian Bahasa Arab. Malang: Hilal Pustaka.

Amrulloh, M.A. \& Hasanah, H. (2019). Analisis kesalahan fonologis membaca teks Bahasa Arab siswa Madrasah Tsanawiyah Lampung Selatan. Arabiyatuna: Jurnal Bahasa Arab, 3(2), 209²28. 
Arwani, M. (2009). Thariqah baca tulis dan menghafal Al-Qur'an Yanbu'a. Kudus: Pondok Tahfidh Yanbu'ul Qur'an Kudus.

Hamid, A., (2013). Teknik pengajaran bunyi Bahasa Arab. Jurnal Al Bayan: Jurnal Jurusan Pendidikan Bahasa Arab, 5(1).

Hidayat, B., (2017). Pembelajaran Al-Qur'an pada anak usia dini menurut psikologi agama dan neurosains. Proceedings of the 2nd Annual Conference on Islamic Early Childhood Education, 2, 59-70.

Kemendikbud, R. I., (2015). Permendikbud Nomor 137 Tahun 2014 Tentang Standar Nasional Pendidikan Anak Usia Dini. Jakarta: Kemendikbud

Mamlu'ah, A., \& Diantika, D.E. (2018). Metode Yanbu'a dalam penanaman kemampuan membaca huruf hijaiyah pada santri TPQ At-Tauhid Tuban. Al-Ulya: Jurnal Pendidikan Islam, 3(2).

Masitoh. (2019). Gangguan bahasa dalam perkembangan bicara anak. Jurnal Elsa, 17(1), $40^{-5} 54$.

Puspita, W.A. (2013). Aspek-aspek penting dalam perkembangan dan pendidikan anak usia dini. JPNF: Jurnal Pendidikan Non-Formal Edisi 10.

Santrock, J.W. (2011). Life-span development: Perkembangan masa hidup edisi 13 Jilid 1, Penerjemah: Widyasinta, B. Jakarta: Erlangga

Slameto. (2013). Belajar dan faktor-faktor yang mempengaruhinya. Jakarta : PT Rineka Cipta.

Tadjuddin, N. (2017). Meneropong perkembangan anak usia dini perspektif Al-Qur'an. Depok: Herya Media.

Tanfidiyah, N. (2017). Metode Yanbu'a dalam meningkatkan prestasi baca tulis Al-Qur'an pada anak usia dini. Proceedings of the 2nd Annual Conference on Islamic Early Childhood Education, 2, 109¹20.

Wicaksono, M.A., \& Inayati, N.L. (2018). Efektifitas metode Yanbu'a dalam meningkatkan kemampuan tahfidz Al-Qur'an di SMP IT AL-Anis Kartasura tahun pelajaran 2017/2018. Jurnal SUHUF, 30(2), 159-160

Widodo, A., Mahbub, N., \& Yani, A. (2017). Metode pembelajaran membaca Al-Qur'an anak usia 7-13 tahun di TPQ Al-Falah 2 Desa Serangkulon Blok 01 RT 01 RW 01 Kecamatan Babakan Kabupaten Cirebon. Jurnal Al-Tarbawi Al Haditsah, 1(2). 